Reprod. Nutr. Dévelop., 1985, 25 (1 A), 113-126.

\title{
The effect of undernutrition of beef cows on blood hormone and metabolite concentrations post partum
}

\author{
M. P. EASDON (1), J. M. CHESWORTH ( $\left.{ }^{2}\right)$, M. B. E. ABOUL-ELA $\left({ }^{3}\right)$, \\ G. D. HENDERSON
}

School of Agriculture,

581 King Street, Aberdeen, AB9 1UD, U.K.

Summary. Twelve Hereford Friesian cows were allocated to either a high plane (HP) or a low plane of nutrition (LP) post-partum. HP animals received rations supplying sufficient energy and protein for maintenance plus $10 \mathrm{~kg} /$ day milk yield. LP cows were offered approximately $70 \%$ of their maintenance needs for 63 days post-partum. Thereafter they received the same ration as the HP animals. A mineral vitamin supplement was included in all concentrates fed. Calves were only permitted to suckle twice daily and all animals were weighed once weekly. Blood samples were taken once daily and the levels of serum progesterone, luteinizing hormone (LH) and prolactin (PRL) estimated. Once weekly blood samples and diurnal samples (once fortnightly) were measured for their content of insulin, non esterified fatty acids (NEFA), glucose, total protein, albumin and urea. Oestrus was detected by visual observation and by intra vaginal electrical resistivity and ovulation was confirmed by rectal palpation. After $\mathbf{1 1 0}$ days all animals were synchronized with two injections of prostaglandin. This was followed by fixed time insemination at 72 and 96 hours.

Time from parturition to first ovulation was: HP; $39 \pm 8.7$ days ; LP, $65,3 \pm 33,2$ days. All HP animals showed regular cyclic ovarian activity whereas only 3 of the $L \bar{P}$ cows were normal (LPR). The ovarian activity of the remaining LP cows (LPI) was almost completely suppressed. Of the animals that cycled normally there was no difference in progesterone concentrations between treatments. Average $\mathrm{LH}$ concentrations did not differ between HP and LP or between LPR and LPI cows.

HP cows maintained their body weight post-partum whilst the LP lost $21.4 \pm 4.40 \%$ by day 63 . Milk yield of the LPI animals was consistently higher than that of the LPR and it was found that the nine regularly cyclic animals had a lower milk yield to body weight ratio than those that failed to cycle properly $(P<0.05)$.

Differences between the HP and LP cows were found in relation to insulin, PRL, glucose, NEFA, urea and albumin concentrations. No variation in these parameters was observed that could explain the divergence in ovarian activity of the LPR and LPI groups.

(1) Present Address : Department of Physiology and Environmental Science, University of Nottingham, Faculty of Agricultural Science, Sutton Bonington, Loughborough, Leicestershire, LE12 5RD.

(2) Present Address : Beech Cottage, Sauchen, Inverurie, Aberdeenshire.

(3) Present Address : Faculty of Agriculture, University of Mansoura, El Mansoura, Egypt. 


\section{Introduction.}

It is well established that under nutrition of cows may result in lengthening of the post-partum interval to onset of ovarian activity (Oxenreider and Wagner, 1971) and oestrus (Holness, Hopley and Hale, 1978) together with a depression in fertility (Dunn et al., 1962 ; Wiltbank et al., 1962 ; Somerville, Lowman and Deas, 1979). However, there is a lack of conclusive studies on the effect of nutrition on post-partum levels of reproductive hormones. No effects on progesterone levels were found by two groups of researchers (Corah et al., 1974 ; Sceery, 1978) whilst peak concentrations of the hormone were observed by Moss et al. (1982) to be lowered. Mean luteinizing hormone levels have been reduced (Gauthier, Terqui and Mauléon, 1983) or have remained constant (Rone, Henricks and Echternkamp, 1982).

The intermediary role of metabolic hormones and blood metabolites in the effect of under-nutrition on reproductive function has not been extensively documented although it has been suggested that hypoglycaemia has a suppressive effect on fertility (McClure, 1968; Downie and Gelman, 1976) and also lengthens the duration of post-partum anoestrus (Benjaminsen, 1977). Some results from field studies have implicated hypoalbuminaemia with reduced fertility (Rowlands, Little and Kitchenham, 1977 ; Rowlands et al., 1980) as have been high levels of free fatty acids (Reid, Roberts and Manston, 1979). Both growth hormone $(\mathrm{GH})$ and insulin may be related to reproductive function in the cow since low levels of the former and high levels of the latter were associated with shorter time spans between calving and first ovulation (Oxenreider, 1968; Carstairs, Morrow and Emery, 1980).

The objectives of this study were (1) to examine the effect of under-nutrition on variables associated with both reproduction and intermediary metabolism (2) to evaluate whether or not differences in ovarian function due to severe underfeeding are associated with differences in blood levels of one or more metabolic hormone or blood metabolite.

\section{Materials and methods.}

Twelve Hereford cross Friesian heifers were brought indoors at approximately the eighth month of pregnancy and allocated at random to either a High Plane (HP) or Low Plane (LP) of nutrition.

The ration fed during the last weeks of pregnancy was the same for all animals. Following parturition the HP cows were offered $112 \mathrm{MJ} / \mathrm{d}$ of metabolizable energy (ME) and $805 \mathrm{~g} / \mathrm{d}$ of digestible crude protein (DCP). During the first 63 days post-partum the LP cows were fed a ration to meet approximately $70 \%$ of their maintenance requirements, i.e. $34 \mathrm{MJ} / \mathrm{d} \mathrm{ME}$ and $171 \mathrm{~g} / \mathrm{d}$ DCP. After a changeover period of 10 days the LP animals were offered the same diet as the HP animals until the end of the experiment. Throughout the experiment $125 \mathrm{~g} / \mathrm{day}$ of a mineral/vitamin supplement was mixed with the concentrate fraction of the diet of all the cows and fresh water was freely available. Each cow was fed individually and any residues were weighed before feeding. 
Suckling by calves was restricted to approximately half-an-hour at feeding times. Both dams and calves were weighed once weekly. Daily milk yield was also estimated once weekly and assumed to be the sum increase in weight of the calves found at 08.00 and 16.00 hours as a result of suckling.

Visual observations for signs of oestrus were made twice daily at $07.30 \mathrm{hr}$ and $15.30 \mathrm{hr}$ while cows remained in their stalls. Oestrus was also detected by measurements of intra-vaginal electrical resistance.

The ovaries were examined per rectum for cyclic activity and ovulation. Palpation was performed weekly during the first 28 days after calving and twice weekly thereafter. 110 days after the first heifer had calved all animals were given an intramuscular injection of $0.5 \mathrm{mg}$ cloprostenol. A second injection was given after 11 days and the cows were artificially inseminated 72 and 96 hours later.

Blood was taken daily by jugular venipuncture throughout the post-partum period before feeding. At approximately two-week intervals a " diurnal " serum sample was obtained at $08.00,10.00,12.00$ and $16.00 \mathrm{hr}$. Serum was prepared and stored at $-20^{\circ} \mathrm{C}$ until required for analysis. In addition, a weekly plasma sample was obtained as well as diurnal plasma samples every two weeks.

The daily serum samples were analysed by radioimmunoassay for luteinizing hormone (LH), prolactin (PRL) (Chesworth, 1977) and progesterone (Abraham, 1969). Insulin levels were measured in serum once weekly (Chesworth, 1977) and diurnally by a similar method. Intra and interassay coefficients of variation are presented in table 1. Albumin concentration and total protein in serum was determined by a method based on that of Bartholomew and Delaney (1967). Nonesterified fatty acids (Baird, Black and Faulkner, 1967), glucose (Trinder, 1969) and urea (Marsh, Fingerhut and Miller, 1965) levels were estimated for each of the plasma samples.

Milk yield, liveweight, concentrations of albumin, NEFA, urea insulin and PRL were compared on a weekly average basis between the HP and LP heifers and between those animals showing regular cyclic ovarian activity and those with irregular cyclic activity by oneway analysis of variance. A similar process was applied to basal $\mathrm{LH}$ values after elimination of those determinations around oestrus. The same comparisons were made with regard to PRL but by analysis of covariance where the covariate was daylength. Averages of serum progesterone concentration during the period from day-15 preceeding to the day after the day of ovulation were calculated. Differences in average progesterone concentration between HP and LP groups were tested by analysis of variance. Pearson product-

TABLE 1

Percent intra and inter assay coefficients of variation of the radioimmunoassay systems.

\begin{tabular}{|c|c|c|}
\hline & Intra & Inter \\
\hline 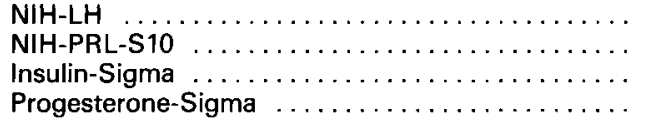 & $\begin{array}{r}4.8 \\
4.7 \\
4.1 \\
10.7\end{array}$ & $\begin{array}{r}5.8 \\
15.2 \\
8.7 \\
17.3\end{array}$ \\
\hline
\end{tabular}


moment correlation coefficients were calculated between milk yield, liveweight and several blood components.

\section{Results.}

All calvings occurred within one month. The average intake of ME and DCP is presented in table 2.

The average time from parturition to first ovulation in the HP cows was $39 \pm 8.7$ days and regular cyclic ovarian activity followed until cloprostenol treatment several weeks later (fig. 1, a-f). The LP animals ovulated for the first time $65.3 \pm 33.2$ days post-partum but there was considerable variation between individuals (fig. 1, g-1). Of all first ovulations, $83 \%$ were unaccompanied by behavioural signs of oestrus. Subsequent occurrence of ovulatory anoestrus was low with little difference between the two groups: HP, $26 \%$; LP, $18 \%$.

Serum progesterone concentrations indicated signs of low level luteal activity during the first 3 weeks post-partum in the HP cows (fig. 1, a-f). In all cases these fluctuations culminated in a short peak before the first ovulation. Thereafter progesterone was secreted in a regular cyclic manner.

In contrast to the HP animals, the LP group exhibited marked variation in luteal function (fig. 1, g-1). Three cows had progesterone profiles similar to the HP group (fig. 1, g, h, i) although 19 and 7 did not show any short rise in progesterone before the first ovulation and the first cycle of 7 was prolonged. The luteal function of the remaining animals was almost completely suppressed (fig. 1, $\mathrm{j}, \mathrm{k}, \mathrm{l}$. . On the basis of these progesterone profiles the LP cows were divided into 2 subgroups : low plane regularly cyclic (LPR), 11, 19 and 7 and low plane irregularly cyclic (LPI), 14, 15 and 8. Subsequent statistical analyses compared these two groups.

The difference between the HP and LP animals in average progesterone concentration was small and insignificant when comparisons were based on data for the period up to day 80 post-partum irrespective of the inclusion of the first ovulation, or for the period between days 80 and 130 irrespective of the inclusion of the synchronized oestrus or for the whole post-partum period.

TABLE 2

The average intake of $M E(\mathrm{MJ} / \mathrm{d})$ and $D C P(\mathrm{~g} / \mathrm{d})$ of the cows post-partum $( \pm \mathrm{SD})$.

\begin{tabular}{|c|c|c|c|}
\hline & & \multicolumn{2}{|c|}{ Postpartum } \\
\hline & & weeks $1-9$ & weeks $10-19$ \\
\hline \multirow{2}{*}{$\begin{array}{c}\mathrm{ME} \\
(\mathrm{MJ} / \mathrm{d})\end{array}$} & HP & $108.8 \pm 7.45$ & $114.8 \pm 4.66$ \\
\hline & LP & $32.3 \pm 5.10$ & $94.7 \pm 14.60$ \\
\hline \multirow{2}{*}{$\begin{array}{c}D C P \\
(\mathrm{~g} / \mathrm{d})\end{array}$} & HP & $785 \pm 52.9$ & $780 \pm 50.7$ \\
\hline & LP & $168 \pm 34.9$ & $692 \pm 125.4$ \\
\hline
\end{tabular}


Basal LH levels remained low throughout the first 63 days post-partum and there was no consistent trend for either nutritional group to have lower values than the other. Similarly, no significant differences were found between the LPR and LPI subgroups. These findings also applied to the diurnal samples.

Throughout the post-partum period the average liveweight of the LP cows was significantly lower $(P<0.001)$ than that of the HP. LP animals lost $21.4 \pm 4.40 \%$ of their initial weight over the first 63 days post-partum and reached a minimum of $352 \pm 0.51 \mathrm{~kg}$. HP cows maintained weight at around $480 \mathrm{~kg}$. There was no difference in percentage weight loss between the LPR and LPI groups.

The milk yield of the LP cows peaked during the first weeks of lactation and then started to decline slowly. In contrast to this pattern the LP milk yield remained significantly lower than that of the HP while the animals were being underfed. Soon after the commencement of refeeding the LP milk yield started to rise. Although there were no significant differences between LPI and LPR milk yield at any stage the consistent trend was for the former to be higher. As a crude estimate of nutritional and lactational stress on the animals the average ratio of the milk yield to liveweight was calculated for each animal. It was found that the nine regularly cyclic animals had a significantly $(P<0.05)$ lower $\left(16.5 \pm 0.66 \mathrm{gd}^{-1} \mathrm{~kg}^{-1}\right)$ milk yield to bodyweight ratio than those that failed to cycle properly $\left(19.7 \pm 1.53 \mathrm{gd}^{-1} \mathrm{~kg}^{-1}\right)$.

There was no consistent trend in serum total protein levels of the HP cows with the concentrations fluctuating between 63 and $70 \mathrm{~g} / \mathrm{l}$. In contrast the LP total protein concentration tended to rise after parturition and reached a peak of $73 \mathrm{~g} / \mathrm{l}$ at day 49 . Thereafter the concentration fell precipitously to a nadir of about $57 \mathrm{~g} / \mathrm{l}$ by day 91 which was followed by a steady increase. No differences were found between LPR and LPI subgroups.

The pattern of albumin concentrations in the two groups was similar to that of total protein. HP concentrations fluctuated between 30 and $34 \mathrm{~g} / \mathrm{I}$ whereas the LP concentration rose to a peak of approximately $35 \mathrm{~g} / \mathrm{l}$ by day 49 . During this period the LP albumin concentration was significantly higher than that of the HP on four occasions (days 28, 35, 42 and 49). Thereafter LP albumin concentrations fell markedly and were significantly lower than the HP on days 91, 105, 112 and 119. There were no differences between the LPR and LPI subgroups.

The plasma urea concentration of the HP group fell sharply from approximately $3.2 \mathrm{mmol} / \mathrm{I}$ after parturition to a minimum of $2.0 \mathrm{mmol} / \mathrm{l}$ at day 28 . This was followed by an almost linear increase in level to $2.6 \mathrm{mmol} / \mathrm{I}$ at day 133 . There were no significant differences between the HP and LP animals. LPI and LPR subgroups were not significantly different.

The concentrations of HP non-esterified fatty acids declined for 5 weeks after parturition and then remained stable throughout the remainder of the experiment fluctuating at around $200 \mathrm{~m}$ equiv/I. In contrast the LP NEFA concentrations were significantly higher than the HP for 63 days (fig. 2). Throughout the experiment LPR and LPI subgroups were not significantly different.

For practically the whole experimental period the HP concentrations of plasma slucose remained significantly higher than those of the LP (fig. 3). During 


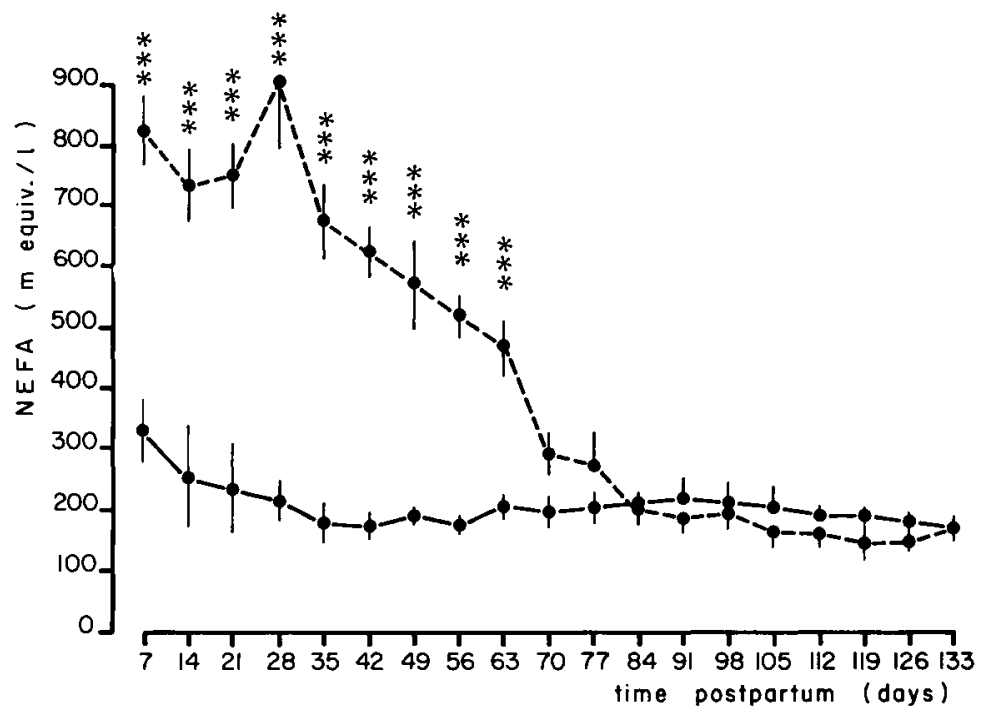

FIG. 2. - The effect of plane of nutrition and days after calving on plasma NEFA levels in $\mathrm{H} \times \mathrm{F}$ cows. High plane of nutrition: - L Low plane of nutrition : - -- . Vertical bars represent \pm SEM $(n=6)$. Significance of differences between the planes of nutrition : ${ }^{*}: P<0.05$; ${ }^{* *}: \mathrm{P}<0.01 ;{ }^{* * *}: \mathrm{P}<0.001$.

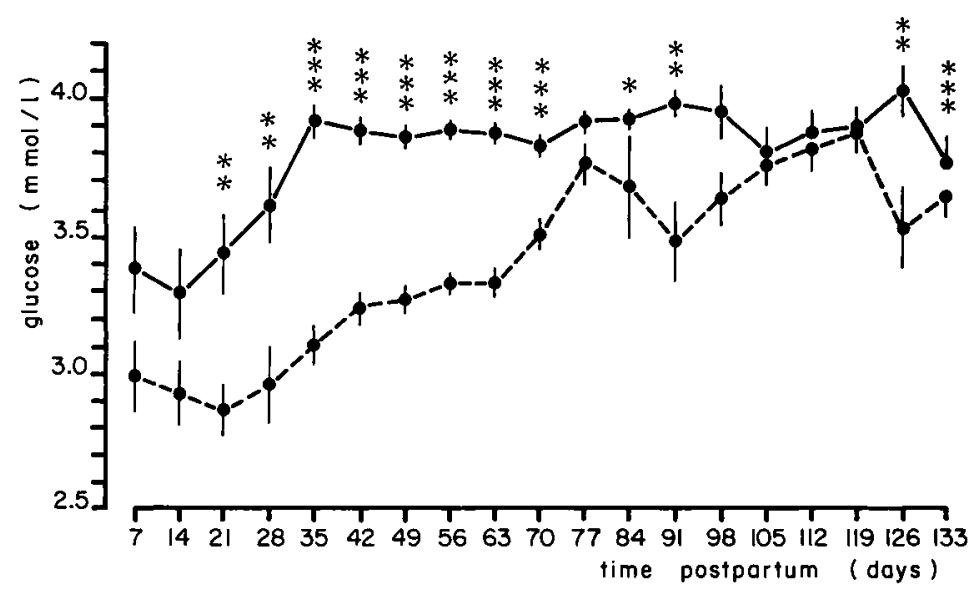

FIG. 3. - The effect of plane of nutrition and time after calving on the concentration of plasma glucose in $\mathrm{H} \times \mathrm{F}$ cows. High plane of nutrition :- Low plane of nutrition : - - - Vertical bars represent \pm SEM $(n=6)$. Significance of differences between the planes of nutrition : ${ }^{*}: \mathrm{P}<0.05 ;{ }^{* *}: \mathrm{P}<0,01 ;{ }^{* *}: \mathrm{P}<0.001$.

the first 14 days post-partum the HP levels were low at around 3.3. mmol/l. From then on there was a steady rise until a plateau was attained at approximately $3.9 \mathrm{mmol} / \mathrm{I}$. LP glucose concentrations declined until day $21(2.9 \mathrm{mmol} / \mathrm{l})$. Thereafter levels rose linearly until they approached those HP at approximately 105 days post-partum. There were no differences between the two LP subgroups. 
Pre-feeding insulin values in both groups fell during the first 35 to 42 days after parturition to approximately 4.0 to $4.5 \mathrm{mU} / \mathrm{l}$. During the following 100 days a slight increase was observed to a maximum of approximately $5.5 \mathrm{mU} / \mathrm{l}$. There were no significant differences between the groups. In the diurnal samples, however, it was noted that there was a marked post-prandial elevation of the insulin concentrations of the HP group. When the averages for the diurnal samples were compared it was found that the insulin level of the HP group was consistently 1.0 to $2.0 \mathrm{mU} / \mathrm{I}$ higher than that of the LP group. This difference was significant $(P<0.01)$ at days 14,28 and 42 post-partum. No differences were observed between the LPR and LPI subgroups.

HP prolactin concentrations fell post-partum to a nadir of approximately $3 \mu \mathrm{g} / \mathrm{l}$ at day 21 . Thereafter there was a gradual increase until a plateau of about $7 \mu \mathrm{g} / \mathrm{I}$ was reached from day 91 onwards (fig. 4). LP prolactin concentrations also decreased post-partum to a minimum of $1.3 \mathrm{~g} / /$ by day 28 . During this period up to day 63 LP concentrations of PRL were significantly lower than those of HP. With the introduction of the re-feeding ration to the LP animals the PRL levels rose quickly until a plateau was reached after day 84 . No differences were noted between the LP subgroups.

Correlation coefficients between the variables measured are shown in table 3 .

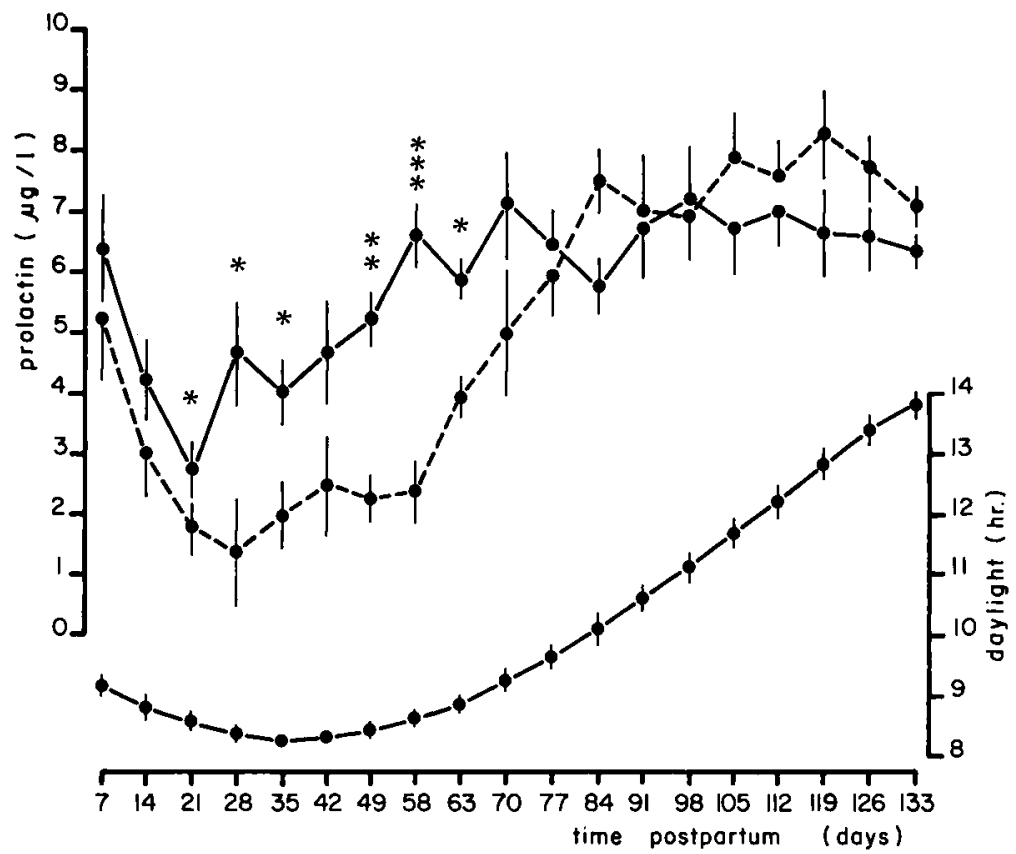

FIG. 4. - The effect of plane of nutrition and time after calving on the concentration of serum prolactin in $\mathrm{H} \times \mathrm{F}$ cows. High plane of nutrition : - Low plane of nutrition : --- . Vertical bars represent \pm SEM $(n=6)$. Values within weeks postpartum are corrected for differences between animals in duration of light exposure. Significance of differences between the planes of nutrition : * $: P<0.05 ;^{* *}: P<0.01 ;^{* * *}: P<0.001$. 
TABLE 3

Correlation coefficients between variables in 12 cows during weeks 1 to 19 postpartum.

\begin{tabular}{|c|c|c|c|c|c|c|c|c|}
\hline & Glucose & Prolactin & Insulin & NEFA & Urea & $\begin{array}{l}\text { Total } \\
\text { protein }\end{array}$ & Albumin & $\begin{array}{l}\text { Live- } \\
\text { weight }\end{array}$ \\
\hline & $* * *$ & & & & & & & \\
\hline $\begin{array}{l}\text { Prolactin } \ldots . \\
\text { Insulin } \ldots \ldots\end{array}$ & $\begin{array}{r}0.377 \\
-0.087 \\
* * *\end{array}$ & $\underset{* * *}{0.032}$ & & & & & & \\
\hline NEFA $\ldots \ldots$ & -0.588 & -0.560 & -0.124 & & & & & \\
\hline Urea ........ & -0.106 & 0.131 & 0.268 & $-\underset{* *}{0.065}$ & & & & \\
\hline Total protein & 0.008 & -0.128 & 0.037 & $\underset{* * *}{0.181}$ & -0.078 & $* * *$ & & \\
\hline Albumin & -0.021 & -0.256 & -0.030 & $\underset{* * *}{0.260}$ & 0.018 & 0.570 & ** & \\
\hline Liveweight .. & $\begin{array}{r}0.301 \\
* * *\end{array}$ & $\begin{array}{r}0.051 \\
* *\end{array}$ & 0.241 & -0.311 & 0.049 & 0.199 & 0.209 & *** \\
\hline Milk yield .... & 0.343 & 0.201 & -0.046 & -0.322 & 0.076 & -0.066 & 0.069 & 0.358 \\
\hline
\end{tabular}

${ }^{* *}=\mathrm{P}<0.001 ;{ }^{* *}=\mathrm{P}<0.01 ;{ }^{*}=\mathrm{P}<0.05$

\section{Discussion.}

The anoestrus period of the HP cows was shorter than that normally observed in suckled beef cows and was undoubtedly due to the restricted access of the calves. Under-nutrition appeared to lengthen the anoestrus period but this was almost entirely due to the suppression of ovarian activity in three cows.

From the limited numbers of animals available it was impossible to determine whether or not the irregular ovarian activity of the LP group was due to the treatment, but it is interesting to note that all of the HP cows showed activity which can be regarded as " normal " from observations made of progesterone levels in dairy cows (Bulman and Lamming, 1978). The only progesterone profile in the LP group which could be classified as following the " normal " pattern was that of heifer 11 (fig. 1, g). Although it is possible that all cows at some time during their lives show some degree of irregularity in ovarian function it appears that in this experiment the cause was primarily due to the low levels of nutrition. The LP cows which cycled $(11,19$ and 7 ; fig. 1) did not have progesterone levels which were significantly different from those in HP suggesting that once ovarian cycles are established luteal function is not altered greatly by underfeeding. The effect of under nutrition did not appear to be gradual but was an " all or nothing " response.

There were no differences at any stage post-partum between the LH levels of the HP or LP groups or between those of the LPR and LPI subgroups. It is possible, however, that the frequency of pulsatile release of the hormone was lower in those animals showing reduced ovarian activity but the frequency of diurnal sampling in this experiment was not great enough to identify any alterations. 
A recent review (Smidt and Farries, 1982) examining the effects of milk yield on fertility has concluded that the results are equivocal and it has been suggested that other factors must be taken into consideration. The relationship between bodyweight loss and milk yield may be more pertinent and this conclusion is supported by the fact that the LPI cows in this trial had a higher milk yield to bodyweight ratio than those which cycled normally.

Total protein was closely correlated with albumin concentration $(P<0.001$; table 3). Both were uncorrelated with milk yield contrary to the findings of Blum et al. (1983) and Kitchenham, Rowlands and Shorbagi (1975). Serum albumin concentration did not rise with advancing lactation. Both albumin and total protein of the HP group remained relatively stable after parturition. The raised concentrations of total protein and albumin during the first several weeks postpartum in the LP group relative to the HP cows may be explained by the fact that there is a time lag of approximately two months before nutritional changes are reflected by the blood proteins (Manston et al., 1975). This is supported by the finding of lower albumin and total protein concentrations in the treated animals during the second half of the experiment suggesting that liver synthesis and/or clearance rates had been affected.

Changes in HP urea levels after parturition were similar to that of other workers (Blum et al., 1983). From previous work (Manston et al., 1975) one might have expected the LP animals, which received much less DCP than the HP animals, to have lower levels of plasma urea during the period of underfeeding. This was not the case and in fact there was a trend for urea to be higher in the underfed cows.

The high levels of NEFA in the LP animals during the underfeeding period suggests that there was significant mobilization of body reserves. Underfeeding is known to elevate levels of NEFA and has been related to ketosis in high vielding dairy cattle early in lactation which exhibit significant weight loss (Brockman, 1979). A similar situation appears to have been the case in the early part of this experiment. The high NEFA levels were associated with falling blood glucose levels and lower insulin concentrations. There was also a significant $(P<0.001)$ negative correlation with body weight. The period of possible ketosis, however, was relatively short-lived and NEFA levels started to drop markedly after day 28 . This fall was significantly $(P<0.001)$ correlated with rising glucose level in the LP animals suggesting that homeostatic mechanisms were in action to correct the metabolic imbalance. The recovery may have been partly due to the falling liveweight resulting in lower maintenance requirements together with a lowered milk yield. The latter was negatively correlated $(r=0.32, P<0.001)$ with NEFA concentration.

The plasma glucose level of the HP cows was lower during the first 28 days post-partum than at other times and this was probably due to lactational stress (Blum et al., 1983) since the liveweight of these animals did not fall after the first week. In the LP animals the nutrient deficiency caused a reduction in blood glucose levels and this is consistent with the findings of other underfeeding experiments (Fisher, Erfle and Sauer, 1971). Although LP glucose concentrations 
fell for four weeks there was a steady increase thereafter and was probably due, as suggested earlier, to a reduction of maintenance and production requirements. Although the blood samples were all taken before feeding there was no significant correlation between glucose and insulin. It would appear that cows are able to maintain glucose levels in spite of changes in other metabolic parameters, nevertheless, glucose was significantly correlated with milk yield and liveweight.

Downie and Gelman (1976) found that, regardless of bodyweight loss, the cows with declining blood glucose levels were infertile whereas the opposite was true in animals which were fertile. This experiment suggests that there may be disorders of ovarian function in animals in which glucose levels are rising toward normal levels from a previously hypoglycaemic state.

As observed by others (Walsh, Vesely and Mahadevan, 1980 ; McAtee and Trenkle, 1971a), insulin values tended to rise with increased lactation length and underfeeding resulted in decreased levels of the hormone. The latter was almost entirely due to the absence of a post-prandial rise in insulin. These facts together with a positive relationship between the hormone and liveweight would support the view that the low levels of insulin in the LP cows were permitting the mobilization of body tissue to meet the deficit in nutrient requirements.

Although the effects were confounded, PRL was significantly correlated with both daylength $(r=0.35 ; P<0.001)$ and time post-partum $(r=0.39$; $P<0.001$ ). The effect of daylength upon PRL levels has been reported by many other workers (see Karg and Schams, 1974) while Webb and Lamming (1981) found a negative relationship between the hormone and stage of lactation. It is also well established that under-nutrition depresses blood PRL levels (McAtee and Trenkle, 1971b) although the nutritional effects were possibly ameliorated by increasing daylength during part of this experiment. Although there is controversy over the hypothesis that PRL is involved in the partition of nutrients between body weight and milk yield post-partum (Swan, 1976; Hart et al., 1978) the present work suggests that the hormone may be anabolic in nature and that low levels permit the mobilization of body tissue. Hyperprolactinaemia does not affect reproductive function in the bovine animal (Williams and Ray, 1980) and there appears to be no evidence to suggest that the hypoprolactinaemia of this experiment would be detrimental.

This work shows that severe under-nutrition of the cow causes metabolic symptoms similar to those of ketosis. Under conditions of prolonged undernutrition, however, the animal is able to correct these imbalances by a combination of reduced body weight and milk yield. Reproductive function is undoubtedly suppressed by under-nutrition but some cows are more resistant to the changes than others. Metabolic parameters which mediate the effects of under-feeding may include glucose, albumin, NEFA and insulin or a combination of all four parameters.

Reçu en septembre 1984.

Accepté en septembre 1984.

Acknowledgements. - We thank Mr. G. Patterson for care of the animals and Mr. D. Keith for blood metabolite analyses. Our thanks also go to Mr. G. Pratt and his staff for the feed analysis. M. P. E. was in receipt of a MAFF scholarship. 
Résumé. Influence de la sous-alimentation sur les concentrations d'hormones et de métabolites dans le sang de vaches à viande après la mise-bas.

Douze vaches (croisées) Hereford $\times$ Frisonnes étaient réparties en deux lots : haut niveau (HP) et bas niveau (LP) de nutrition post-partum. Les vaches à haut niveau recevaient une ration apportant suffisamment d'énergie pour satisfaire leurs besoins d'entretien et permettre une production laitière de $10 \mathrm{~kg} /$ jour. Les vaches à bas niveau recevaient l'équivalent d'environ $70 \%$ de leurs besoins d'entretien pendant les 63 premiers jours postpartum, puis la même ration que les animaux à haut niveau. Tous les aliments concentrés étaient complémentés en minéraux et vitamines. Les veaux n'étaient autorisés à téter leurs mères que deux fois par jour et tous les animaux étaient pesés une fois par semaine. Des échantillons de sang étaient prélevés une fois par jour pour le dosage, dans le sérum, de la progestérone, de $\mathrm{LH}$ et de la prolactine (PRL). Un échantillon par semaine et des échantillons diurnes (une fois tous les quinze jours) de sang étaient analysés pour doser l'insuline, les acides gras non estérifiés (NEFA), le glucose, les protéines totales, l'albumine et l'urée. La détection d'œestrus était faite par observation du comportement et par mesure de la résistivité électrique intra-vaginale et l'ovulation était confirmée par palpation rectale. A 110 jours post-partum tous les animaux étaient synchronisés avec deux injections de prostaglandines. Ils étaient inséminés deux fois, $72 \mathrm{~h}$ et $96 \mathrm{~h}$ après la dernière injection.

L'intervalle parturition - première ovulation était : HP, $39 \pm 8,7$ jours ; LP $65,3 \pm 33,2$ jours. Tous les animaux HP présentèrent une activité cyclique ovarienne régulière tandis que seulement trois vaches LP étaient normales (LPR). L'activité ovarienne des vaches LP restantes était presque complètement supprimée (LPI). Parmi les animaux présentant des cycles normaux, il n'y avait aucune différence quant aux concentrations de progestérone entre les traitements. Les concentrations moyennes de $\mathrm{LH}$ ne différaient ni entre les vaches HP et LP ni entre les vaches LPR et LPI.

Les vaches HP ont conservé leur poids vif post-partum tandis que les vaches LP avaient perdu $21,4 \pm 4,4 \% 63$ jours après le part. La production laitière des animaux LPI était toujours plus élevée que celle des LPR et l'analyse révèle que les 9 animaux présentant des cycles réguliers avaient un rapport production laitière/poids vif plus bas que ceux non cycliques $(P<0,05)$.

Des différences ont été trouvées entre les vaches HP et LP concernant les concentrations d'insuline, PRL, glucose, NEFA, urée et albumine. Aucune variation observée de ces paramètres n'a permis d'expliquer la différence d'activité ovarienne des groupes LPR et LPI.

\section{References}

ABRAHAM G. E., 1969. Solid phase radioimmunoassay of estradiol-17 $\beta$. J. clin. Endocrinol. Metab., 29, 866-870.

BAIRD J., BLACK M. W., FAULKNER D. E., 1967. Semi-automated method for the determination of free fatty acids in plasma. J. clin. Path., 20, 905-909.

BARTHOLOMEW R. J., DELANEY A. M., 1967. Dyebinding technique of determining serum albumin. Assoc. clin. Biochem. sci. techn. Commun. Techn. Bull., No. 11.

BENJAMINSEN E., 1977. Plasma progesterone and ovarian findings related to plasms glucose and acetoacetate in the postpartum period in the cow. Nord. vet. Med., 29, 337-342.

BLUM J. W., KUNZ P., LEUENBERGER H., GAUTSCHI K., KELLER M., 1983. Thyroid hormones, blood plasma metabolites and heamatological parameters in relationship to milk yield in dairy cows. Anim. Prod., 36, 93-104.

BROCKMAN R. P., 1979. Roles for insulin and glucagon in the development of ruminant ketosis. A review. Can. vet. J., 20, 121-126.

BULMAN D. C., LAMMING G. E., 1978. Milk progesterone levels in relation to conception, repeat breeding and fators influencing acyclicity in dairy cows. J. Reprod. Fert., 54, 447-458.

CARSTAIRS J. A., MORROW D. A., EMERY R. S., 1980. Postpartum reproductive function of dairy cows as influenced by energy and phosphorus status. J. anim. Sci., 51, 1122-1130. 
CHESWORTH J. M., 1977. Radioimmunoassay of ovine LH and ovine prolactin using polymerised second antisera. Analyt. Biochem., 80, 31-40.

CORAH L. R., QUEALY A. P., DUNN T. G., KALTENBACH C. C., 1974. Prepartum and post partum levels of progesterone and estradiol in beef heifers fed two levels of energy. J. anim. Sci., 39, 380-385.

DOWNIE J. G., GELMAN A. L., 1976. The relationship between changes in bodyweight, plasma glucose and fertility in beef cows. Vet. Rec., 99, 210-212.

DUNN T. G., INGALLS J. E., ZIMMERMAN D. R., WILTBANK J. N., 1962. Reproductive performance of 2-year old Hereford and Angus heifers as influenced by pre- and post-calving energy intake. J. anim. Sci., 29, 719-726.

FISHER L. J., ERFLE J. D., SAUER F. D., 1971. Inducement of ketotic symptoms in lactating cows by reducing their plane of nutrition. Can. J. anim. Sci., 51, 153-160.

GAUTHIER D., TERQUI M., MAULÉON P., 1983. Influence of nutrition on pre-partum plasma levels of progesterone and total oestrogens and post-partum plasma levels of luteinizing hormone and follicle stimulating hormone in suckling cows. Anim. Prod., 37, 89-96.

HART I. C., BINES J. A., MORANT S. V., RIDLEY J. L., 1978. Endocrine control of energy metabolism in the cow : Comparison of the levels of hormones (prolactin, growth hormone, insulin and thyroxine) and metabolites in the plasma of high- and low-yielding cattle at various stages of lactation. $J$. Endocr., $7,333-345$.

HOLNESS D. H., HOPLEY J. D. H., HALE D. H., 1978. The effects of plane of nutrition, liveweight, temporary weaning and breed on the occurrence of oestrus in beef cows during the postpartum period. Anim. Prod., 26, 47-54.

KARG H., SCHAMS D., 1974. Prolactin release in cattle. J. Reprod. Fert., 39, 463-472.

KITCHENHAM B. A., ROWLANDS G. J., SHORBAGI H., 1975. Relationships of concentrations of certain blood constituents with milk yield and age of cows in dairy herds. Res. vet. Sci., 18, 249-252.

MANSTON R., RUSSELL A. M., DEW S. M., PAYNE J. M., 1975. The influence of dietary protein upon blood composition in dairy cows. Vet. Rec., 96, 497-502.

MARSH W. H., FINGERHUT B., MILLER H., 1965. Automated and manual direct methods for determination of blood urea. Clin. Chem., 11, 624-627.

McATEE J. W., TRENKLE A., 1971a. Metabolic regulation of plasma insulin levels in cattle. J. anim. Sci., 33, 438-442.

McATEE J. W., TRENKLE A., 1971b. Effects of feeding, fasting, glucose or arginine on plasma prolactin levels in the bovine. Endocrinology, 89, 730-734.

MCCLURE T. J., 1968. Hypoglycaemia, an apparent cause of infertility of lactating cows. Br. vet. J., 124, 126-130.

MOSS G. E., PARFET J. R., DIEKMAN M. A., LEMENAGER R. P., HENDRIX K. S., $1982 . \quad$ Pituitary luteninizing hormone (LH), follicle stimulating hormone (FSH), serum progesterone (P) and hypothalamic gonadotrophin-releasing hormone $(\mathrm{GnRH})$ in beef cows in varied body condition. J. anim. Sci., 55 (Suppl. 1), (Abstr.) 374.

OXENREIDER S. L., 1968. Effects of suckling and ovarian function on postpartum reproductive activity in beef cows. Am. J. vet. Res., 29, 2099-2102.

OXENREIOER S. L., WAGNER W. C., 1971. Effect of lactation and energy intake on postpartum ovarian activity in the cow. J. anim. Sci, 33, 1026-1031.

REID I. M., ROBERTS C. J., MANSTON R., 1979. Reduced fertility associated with fatty liver in high-yielding dairy cows. Vet. sci. Commun., 3, 231-236.

RONE J. D., HENRICKS D. M., ECHTERNKAMP S. E., 1982. The influence of energy intake on pituitary and ovarian hormone secretion in the young individually fed post partum beef cow. J. anim. Sci., 55 (Suppl.), 385-386 (Abstr.).

ROWLANDS G. J., LITTLE W., KITCHENHAM B. A., 1977. Relationships between blood composition and fertility in dairy cows - a field study. J. Dairy Res., 44, 1-7.

ROWLANDS G. J., MANSTON R., STARK A. J., RUSSELL A. M., COLLIS K. A., COLLIS S. C., 1980. Changes in albumin, globulin, glucose and cholesterol concentrations in the blood of dairy cows in later pregnancy and early lactation and relationships with subsequent fertility. J. agric. Sci. Camb., 94, 517-527.

SCEERY E. J., 1978. Influence of nutritional and weaning status on plasma progesterone, estradiol- 
$17 \beta$ and reproductive patterns in two year old primiparous Hereford heifers. Diss. Abstr. int., 38B, 5782B.

SMIDT D., FARRIES E, 1982. The impact of lactational performance on post partum fertility in dairy cows, 358-383. In KARG H., SCHALLENBERGER E., Factors Influencing fertility in the postpartum cow. Martinus Nijhoff, The Hague, 358-383.

SOMERVILLE S. H., LOWMAN B. G., DEAS D. W., 1979. The effect of plane of nutrition during lactation on the reproductive performance of beef cows. Vet. Rec., 104, 95-97.

SWAN H., 1976. The physiological interrelationship of reproduction lactation and nutrition in the cow, 85-102. In H. SWAN, W. H. BROSTER, Principles of cattle production. Butterworths, London.

TRINDER P., 1969. Determination of glucose in blood using glucose oxidase with an alternative oxygen acceptor. Ann. clin. Bioch., 6, 24-27.

WALSH D. S., VESELY J. A., MAHADEVAN S., 1980. Relationship between milk production and circulating hormones in dairy cows. J. Dairy Sci., 63, 290-294.

WEBB R., LAMMING G. E., 1981. Patterns of plasma prolactin in postpartum suckled cows. J. Endocr., 90, 391-396.

WILLIAMS G. L., RAY D. E., 1980. Hormonal and reproductive profiles of early post partum beef heifers after prolactin suppression or steroid-induced luteal function. J. anim. Sci, 50, 906918.

WILTBANK J. N., ROWDEN W. W., INGALLS J. E., GREGORY K. E., KOCH R. M., 1962. Effect of energy level on reproductive phenomena of mature Hereford cows. J. anim. Sci, 21, 219-225. 